\title{
A Study on the Teacher Efficacy of Korean Language Teachers
}

\author{
Sang-soo Kim 1 )
}

\begin{abstract}
The purpose of this study is to observe the teacher efficacy of Korean teachers who are working in the Korean language education institutions of universities. Teacher efficacy means the individual's beliefs and perceptions about the degree to which the teacher will have a positive influence on learners' learning. In other words, it can be said that the influence of teachers on the learning of learning materials that teachers perceive is subjective. This is because teacher efficacy measures and reflects the underlying beliefs that can explain the teacher's behavior. This study investigated 31 Korean language teachers. The measurement items were self- regulatory efficacy, self-confidence, and task difficulty. This was divided into subject area, living area, interpersonal relationships, administrative work, and detailed activities. Self-regulated efficacy was 3.6129, self-confidence was 3.1106, and task difficulty preference was 3.1613. In general, the teacher' efficacy of Korean language teachers seems to be positive, but it seems necessary to establish ways to improve their efficacy in order to improve professionalism.
\end{abstract}

Keywords : Teacher Efficacy, Korean Language Teacher, Korean Language Class, Teachers' Beliefs, Second Language

\section{Introduction}

The purpose of this study is to investigate the teacher efficacy of Korean language teachers who are increasing rapidly in number. Foreign students who want to study in universities have diverse educational needs and learning objectives. The efficacy of Korean language teachers is thought to have a significant effect on the improvement of their Korean language ability and adaptation to the university. Therefore, observing and exploring the efficacy of Korean language teachers can be a meaningful task in discussing policy regarding foreign students by the government or universities, teacher education, and the operation of Korean language courses[1].

The quality of education does not exceed the quality of teachers. The meaning of this sentence is that the role of the teacher in educational activities is important. Efforts to promote teachers' instructional practices and to increase teaching ability lead to educational achievement. Therefore, in many advanced countries, much effort is made to nurture and secure excellent,

Received(November 07, 2018), Review Result(1st: November 26, 2018, 2nd: January 4, 2019), Accepted(March 10, 2019)

1) (Assistant Professor) 48520 School of Free Majors, Tongmyong Univ., Sinseonro 428, Nam-gu, Busan, Korea email: kospora@naver.com 
professional teachers. This is why it is important to emphasize teacher education on the knowledge of curriculum content and methods of teaching curriculum content[2].

However, the results of teacher education on the knowledge of curriculum contents and methods of teaching curriculum are not the same in school classroom. In other words, efforts for teacher education are not always consistent with the results of teacher education. This is because teachers' variables, the subject of education, intervene and influence them. Because the values, beliefs, goals, and qualities of teachers influence the teaching process and teaching methods, the efforts and results of teacher education do not correspond with each other[3]. In order to solve these problems, many researchers have become interested in the psychological factor of "teacher efficacy".

Teacher efficacy generally refers to an individual's beliefs and perceptions about how much positive influence teachers have on students' learning[4-6]. Therefore, teacher efficacy research can be regarded as a study of teachers themselves who have a primary interest in how teachers' efficacy will influence their behavior, such as teaching behavior in various educational situations[7].

Recently, several studies have reported that teacher efficacy may affect student learning and achievement. Armor et al. and Berman conceptualized teacher efficacy in a Rand study as the extent that teachers believe they have the ability to influence student outcomes[8]. Ashton and Webb defined teacher beliefs as one of the personal characteristics of teachers related to student achievement that can help students with learning problem[9]. Tschannen-Moran, Woolfolk-Hoy and Hoy defined teachers' beliefs about the ability to execute and organize the actions required to successfully perform a specific teaching task in a particular context[10]. Bandura regarded these teachers' beliefs as a kind of belief system based on teacher's own assessment of teacher effectiveness[11].

A teacher with high teacher efficacy chooses concrete and challenging goals to move in the right direction without compromising or retreating from conflicts with school administrators or challenging and adventurous situations. In addition, teacher efficacy also influences teachers' general view of specific educational activities and educational processes[12]. In other words, teachers with low educational efficacy tend to have pessimistic, protective interests about student motivation, emphasize strict control of class activities, and use external incentives or negative constraints to study students[13].

According to Kim, teacher efficacy can be explained as a major factor of teacher professionalism that can promote students' internal motivation[14]. Teacher efficacy has a real impact on instruction and student guidance, which can affect students' academic self-efficacy 
and motivation. In other words, teacher efficacy will help students improve their academic achievement and school adjustment.

The purpose of this study is to observe the teacher efficacy of Korean language teachers. So far, research on teacher efficacy in Korean language teachers is lacking. The study of teacher efficacy should be accompanied by a macro analysis of teachers' personal characteristics as well as a macro analysis of the environmental factors of teachers. The research questions for this are as follows.

1. What is the perceived level of teacher efficacy of Korean language teachers?

2. What is the relevance of teachers' variables and teacher efficacy?

\section{Methods}

\subsection{Participants}

This study was conducted on 30 Korean language teachers who are working in the Korean language education institutions of universities. The participants were three males and 28 females. The ages of the participants were 14 in their 20s, 13 in their 30s, 3 in their 40s, and one in their 50s. There were 10 master's course, six master's degree, 13 doctoral course and two doctoral degree holders. Basic information on the participants is shown in [Table 1].

[Table 1] Participants

\begin{tabular}{|c|c|}
\hline Gender & $\begin{array}{lr}\text { Male } & 3 \\
\text { Female } & 28 \\
\text { Total } & 31\end{array}$ \\
\hline Age & $\begin{array}{lr}20 \text { 's } & 14 \\
30 \text { s } & 13 \\
40 s & 3 \\
50 s & 1\end{array}$ \\
\hline $\begin{array}{c}\text { Academic } \\
\text { ability }\end{array}$ & $\begin{array}{lr}\text { Master's course } & 10 \\
\text { Master's } & 6 \\
\text { Doctoral course } & 13 \\
\text { Doctor } & 2\end{array}$ \\
\hline
\end{tabular}




\begin{tabular}{|l|l|}
\hline & Less than 1 year -7 \\
& More than 1 year $\sim$ Less than 3 years -9 \\
Educational & More than 3 years $\sim$ Less than 5 years -3 \\
background & More than 5 years $\sim$ Less than 7 years -6 \\
& More than 7 years $\sim$ Less than 10 years -4 \\
& More than 10 years -2 \\
\hline
\end{tabular}

\subsection{Instrument}

Teacher efficacy was measured using a questionnaire based on the Academic Self-Regulation Questionnaire(SRQ-A)[15][16]. Questionnaires were translated into the Korean language. The teacher efficacy suggested by the questionnaire consisted of three items: Self-regulation efficacy, self-confidence and task difficulty preference. Each question was composed of one to six items, totaling 24 items.

\subsection{Procedures and Data Analysis}

The collected data was analyzed using the SPSS 20.0 program. After the completion of an internal consistency reliability measurement, Descriptive Analysis and Pearson correlation analysis was performed to investigate. In this study, the questionnaire was revised to be applicable to Korean language teachers. Firstly, the survey was carried out in the mode of a survey from July to September 2018. Data analysis was then conducted from September to October 2018 after collection of the questionnaires was completed.

\section{Results}

\subsection{Descriptive Statistics}

Teacher efficacy consisted of three items: self-regulation efficacy, self-confidence, and task difficulty. Self-regulated efficacy consisted of SRC, SRA, and SRI. Self-efficacy consisted of SCC, SCG, and SCI. Task difficulty consisted of TDC, TDG, TDI, TDA and TDA. A descriptive statistical analysis was conducted to examine the differences in teacher efficacy. According to 
the results of the analysis of variance, teacher efficacy was high in order of Self-regulation efficacy $(M=3.61)$, Task difficulty preference $(M=3.16)$ and Self-confidence $(M=3.11)$.

[Table 2] Descriptive Statistics

\begin{tabular}{|c|c|c|c|c|}
\hline \multicolumn{2}{|c|}{ Type } & Item & M. & S.D. \\
\hline \multirow{3}{*}{ Self-regulation efficacy } & SRC & 5 & & \\
& SRG & 4 & 3.6129 & .44898 \\
& SRI & 2 & & \\
\hline \multirow{2}{*}{ Self-confidence } & SCC & 4 & & \\
& SCG & 1 & 3.1106 & .69665 \\
& SCI & 2 & & \\
\hline \multirow{3}{*}{ Task difficulty preference } & TDC & 2 & & \\
& TDG & 2 & & \\
& TDI & 2 & 3.1613 & \\
& TDA & 1 & & \\
& TDS & 2 & & \\
\hline
\end{tabular}

Teacher's confidence is the degree of confidence or belief in the individual's abilities. Therefore, teachers' self-confidence is a judgment of an individual teachers' ability to take necessary actions that are expected to be desirable in school settings[17]. This self-confidence is established through cognitive judgment process and expressed as an emotional reaction[18].

Self-regulatory efficacy is an expectation of efficacy on whether a teacher can positively use self-regulating mechanisms such as observing activities, self-judgment, and self-reacting in school. Self-regulation efficacy appears as self-observation, self-judgment, and self-response. Self-observation is about providing information about what you do and setting goals. And it evaluates the progress of a task and induces a change in behavior. Self-judgment is the determination of the affirmative or negative nature of performance by comparing its goal with its current performance. Self-reaction is a reaction that adjusts behavior according to the satisfaction of the target process and synchronizes itself to improve it.

Task difficulty preference is the degree of preference for task difficulty associated with a goal. Teachers with high teacher efficacy choose concrete goals to move in a desirable direction without compromising with school administrators or in challenging and adventurous situations[19]. On the other hand, teachers with low teacher efficacy are afraid and avoid threat 
situations that transcend their skills, and they choose and act only in situations that they feel they can control. Task difficulty preference is revealed through the process of selecting challenging tasks that the teacher feels can be controlled and manipulated.

\subsection{Correlation}

The correlation between types of teacher efficacy is shown in the following [Table 3]. Among the factors of teacher efficacy, the correlation between self-regulated efficacy and task difficulty was found to be high. And there was also a correlation between self-confidence and task difficulty.

[Table 3] Correlation

\begin{tabular}{|c|c|c|c|c|}
\hline & & $\begin{array}{c}\text { Self-regulation } \\
\text { efficacy }\end{array}$ & $\begin{array}{c}\text { Self- } \\
\text { confidence }\end{array}$ & $\begin{array}{c}\text { Task difficulty } \\
\text { preference }\end{array}$ \\
\hline \multirow{3}{*}{$\begin{array}{l}\text { Self-regulation } \\
\text { efficacy }\end{array}$} & Correlation & 1 & .071 & $.560^{* *}$ \\
\hline & p-value & & .703 & .001 \\
\hline & $\mathrm{N}$ & 31 & 31 & 31 \\
\hline \multirow{3}{*}{ Self-confidence } & Correlation & .071 & 1 & $.377^{*}$ \\
\hline & $p$-value & .703 & & .037 \\
\hline & $\mathrm{N}$ & 31 & 31 & 31 \\
\hline \multirow{3}{*}{$\begin{array}{l}\text { Task difficulty } \\
\text { preference }\end{array}$} & Correlation & $.560^{* *}$ & $.377^{*}$ & 1 \\
\hline & p-value & .001 & .037 & \\
\hline & $\mathrm{N}$ & 31 & 31 & 31 \\
\hline
\end{tabular}

$* * \mathrm{p}<0.01$

\subsection{Multivariate Analysis}

The results of this study are as follows. First, it was confirmed that the teacher's age, academic 
ability, and educational experience affect self-regulated efficacy, self-confidence, and task difficulty preference. As a result, the $F$ value of self-regulated efficacy was within the significance level, and the age self-regulated efficacy was 6.789, academic ability self-regulation efficacy was 5.187, and educational experience self-regulated efficacy was 3.391 .

[Table 4] Multivariate Analysis

\begin{tabular}{|c|c|c|c|c|c|c|}
\hline \multicolumn{2}{|c|}{ variables } & S. & D.F. & M.S. & $\mathrm{F}$ & p-value \\
\hline \multirow{3}{*}{ Age } & $\begin{array}{c}\text { a. Self-regulation } \\
\text { efficacy }\end{array}$ & 1.815 & 3 & .605 & 6.789 & .003 \\
\hline & b. Self-confidence & 958 & 3 & .319 & .551 & .654 \\
\hline & $\begin{array}{l}\text { c. Task difficulty } \\
\text { preference }\end{array}$ & .942 & 3 & .314 & 2.786 & .072 \\
\hline \multirow{3}{*}{$\begin{array}{l}\text { Academic } \\
\text { ability }\end{array}$} & $\begin{array}{c}\text { a. Self-regulation } \\
\text { efficacy }\end{array}$ & 1.209 & 4 & .302 & 3.391 & .033 \\
\hline & b. Self-confidence & 1.275 & 4 & .319 & .550 & .702 \\
\hline & $\begin{array}{l}\text { c. Task difficulty } \\
\text { preference }\end{array}$ & 1.273 & 4 & .318 & 2.824 & .058 \\
\hline \multirow{3}{*}{$\begin{array}{l}\text { Educational } \\
\text { experience }\end{array}$} & $\begin{array}{c}\text { a. Self-regulation } \\
\text { efficacy }\end{array}$ & .924 & 2 & .462 & 5.187 & .017 \\
\hline & b. Self-confidence & 2.008 & 2 & 1.004 & 1.732 & .207 \\
\hline & $\begin{array}{l}\text { c. Task difficulty } \\
\text { preference }\end{array}$ & .482 & 2 & .241 & 2.136 & .149 \\
\hline
\end{tabular}

\section{Conclusion}

In a second language classroom, such as Korean language class, the teacher's speech and behaviors become an important input and model for learners' language acquisition. In addition, teachers' attitudes and antagonisms have a great influence on psychological factors such as learners' motivation, anxiety, and self-efficacy.

The importance of the role of teacher and the necessity of in-depth research are emphasized constantly in Korean language education research, but they are insufficient compared to other research fields. Although there have been discussions on good teachers, research on teacher 
factors such as teachers' values, beliefs, goals, qualities, and experiences that affect curriculum and teaching methods have been limited[20]. This is because researchers in the field of Korean language education are not only interested in teachers' factors but also the complexity and ambiguity of measuring teachers' beliefs and values.

Teacher efficacy means the individual's beliefs and perceptions about the degree to which the teacher will have a positive influence on learners' learning[21][22]. In other words, it can be said that the influence of teachers on the learning of learning materials that teachers perceive is subjective. This is because teacher efficacy measures and reflects the underlying beliefs that can explain the teacher's behavior.

In this study, we measured the teacher efficacy of Korean language teachers and analyzed how the variables of teachers affect the teacher efficacy of Korean language teachers. In general, the teacher' efficacy of Korean language teachers seems to be positive, but it seems necessary to establish ways to improve their efficacy in order to improve professionalism.

\section{References}

[1] S. Kim, A Study on Teachers' Perceptions and Prospects on Korean Language Education Policy, Asia-pacific Journal of Multimedia Services Convergent with Art, Humanities, and Sociology, (2018), Vol.8, No.8, pp.557-566, DOI: 10.35873/ajmahs.2018.8.8.053

[2] P. T. Ashton, Teacher efficacy: A motivational paradigm for effective teacher education, Journal of Teacher Education, (1984), Vol.35, No.5, pp.28-32, DOI: https://doi.org/10.1177/002248718403500507

[3] T. R. Guskey, P. D. Pissaro, Teacher efficacy : A Study of construct dimension, American Educational Research, (1994), Vol.31, No.3, pp.625-643, DOI: https://doi.org/10.2307/1163230

[4] S. Kwak, M. Yoon, Development and Validation of Teacher Efficacy Scale for Elementary School Teachers, Korean Journal of Education Psychology, (2016), Vol.30, No.3, pp.559-583, DOI: 10.17286/KJEP.2016.30.3.04

[5] S. Kwak, M. Yoon, Basic Study on Self-efficacy Scale Development for Elementary School Teachers, Korean Journal of Education Psychology, (2014), Vol.28, No.4, pp.761-782, DOI: 10.17286/KJEP.2014.28.4.10

[6] Y. Park, S. Choi, The Study of Teacher Efficacy Constructs in Korean Language Arts, Journal of Learner-Centered Curriculum and Instruction, (2009), Vol.9, No.1, pp.241-272, UCI: G704-001586.2009.9.1.012

[7] A. Bandura, F. J. Jourden, Self-regulatory mechanisms governing the impact of social comparison on complex decision making, Department of Psychology, Stanford University, Unpublished manuscript, (1991)

[8] D. J. Armor, P. C. Oseguera, M. Cox, N. J. King, L. M. McDonnell, A. H. Pascal, E. Pauly, G. L. 
Zellman, Analysis of the school preferred reading program in selected, Los Angeles minority schools, Rand Corporation, (1976)

[9] P. T. Ashton, R. B. Webb, Making a difference: Teachers' sense of efficacy and student achievement, Addison-Wesley Longman, (1986)

[10] M. T. Moran, A. W. Hoy, Teacher efficacy: Capturing an elusive construct, Teaching and Teacher Education, (2001), Vol.17, No.7, pp.783-805, DOI: https://doi.org/10.1016/S0742-051X(01)00036-1

[11] A. Bandura, R. E. Wood, Effect of perceived controllability and performance standards on self-regulation of complex decision-making, Journal of Personality and Social Psychology, (1989), Vol.56, No.5, pp.805-814, DOI: $10.1037 / 0022-3514.56 .5 .805$

[12] E. Hur, S. Jung, A study of the Research Trends on Pre-service Education Studies in Korea, Korean Journal of Educational Research, (2013), Vol.51, No.4, pp.1-25, UCI: G704-000614.2013.51.4.004

[13] A. Bandura, Self-efficacy: the exercise of control, W. H. Freeman, (1997)

[14] A. Kim, M. Kim, Validation of Teacher-Efficacy Scale, Korean Journal of Education Psychology, (2004), Vol.18, No.1, pp.37-58, UCI: G704-000199.2004.18.1.005

[15] Y. Jung, A Study on the Self-determination Motivation of Saudi Arabians as korean Language learners, The Journal of Learner-Centered Curriculum and Instruction, (2016), Vol.16, No.7, pp.319-338, UCI: G704-001586.2016.16.7.020

[16] B. Bak, J. Lee, S. Hong, Reconstructing the classificatory pattern of Learning motivation proposed by self-determination theory, Korean Journal of educational Psychology, (2005), Vol.19, No.3, pp.699-717.

[17] S. Kim, A Study on Educational Beliefs of Korean Teachers, Asia-pacific Journal of Multimedia Services Convergent with Art, Humanities, and Sociology, (2018), Vol.8, No.4, pp.597-605, DOI: 10.35873/ajmahs.2018.8.4.054

[18] A. Bandura, Perceived self efficacy in cognitive development and functioning, Educational Psychologist, (1994), Vol.28, No.2, pp.117-148, DOI: https://doi.org/10.1207/s15326985ep2802_3

[19] J. Yang, B. Kim, Comparative Analysis of Beliefs about Language Learning between Pre-service English and Early Childhood Teachers, Asia-pacific Journal of Multimedia Services Convergent with Art, Humanities, and Sociology, (2017), Vol.7, No.2, pp.761-769, DOI: 10.35873/ajmahs.2017.7.2.072

[20] E. K. Horwitz, The beliefs about language learning of beginning university foreign language student, The Modern language Journal, (1988), Vol.72, No.3, pp.283-294, DOI: https://doi.org/10.2307/327506

[21] M. Jee, Beliefs about language learning: A study of American university students learning Korean, Language Research, (2013), Vol.49, No.2, pp.399-418, UCI: G704-000435.2013.49.2.013

[22] M. Jee, Affective factors in Korean as a foreign language: Anxiety and beliefs, Language Culture and Curriculum, (2014), Vol.27, No.2, pp.182-195, DOI: 10.1080/07908318.2014.918626 